\author{
dr Ksymena Rosiek \\ Uniwersytet Ekonomiczny w Krakowie \\ Katedra Polityki Przemysłowej i Ekologicznej \\ e-mail:ksymena.rosiek@uek.krakow.pl
}

\title{
WODY OPADOWE JAKO PRZEDMIOT GOSPODAROWANIA
}

\author{
RAINWATERS AS AN OBJECT FOR MANAGEMENT
}

\begin{abstract}
Rainwater should be treated as an precious asset not like waste or sewage. It should be cautiously managed in order to reduce risk of flooding, floods and drought protection. It enable improving quality of life on the urban area and ensure better watering on the rural area. Natural processes for its purification can and should be used.

The paper is the first step in a border research connected with rainwater management. The main goal of it is to recognize the scope range of rainwater problems in the context of its management, defining problems ant their roots and goals for effectiveness rainwater management.
\end{abstract}

Keywords: rain water management, stormwater management, goals of rainwater management JEL classification: Q250 Renewable Resources and Conservation: Water

\section{Wstęp}

W ostatnich dekadach woda często postrzegana była po prostu jako surowiec dla gospodarki, rzeki jako zagrożenie powodziowe, a systemy naturalnej retencji - takie jak moczary, bagna - jako zajmujące przestrzeń nieużytki. Z jednej strony opady nawalne, a z drugiej nękające wiele obszarów susze powodują, że niezbędne staje się zaproponowanie innego podejścia do wód opadowych. Dotychczas woda deszczowa była traktowana jako ,problem”, ściek i odpad, a najczęściej wybieranym rozwiązaniem, zwłaszcza na terenach zurbanizowanych, było jej zebranie i odprowadzenie $\mathrm{z}$ terenu zabudowanego. W połączeniu z nasilającym się utwardzaniem powierzchni i rosnącym udziałem powierzchni nieprzepuszczalnej, osuszaniem i degradowaniem naturalnych obszarów retencyjnych powoduje to narastanie problemów z wodą deszczową, a nie ich rozwiązywanie. Po prostu obszar 
nieprzepuszczalny, z którego woda deszczowa spływa, staje się tak duży, że każda instalacja odprowadzająca staje się niewydolna.

Woda deszczowa powinna zacząć być traktowana nie jako odpad, a jako cenny zasób, którym należy mądrze gospodarować w celu zmniejszenia ryzyka podtopień i powodzi, przeciwdziałania suszy, poprawy jakości życia na terenach zurbanizowanych, zapewnienia nawodnień dla rolnictwa. Można i należy wykorzystywać naturalne procesy w celu oczyszczania tejże wody.

Proponowane rozważania są pierwszym etapem szerszych badań związanych z gospodarowaniem wodami opadowymi. Celem artykułu jest rozpoznanie tematyki wody deszczowej w kontekście problemów z zarządzaniem nią, zdefiniowanie problemów i ich przyczyn oraz celów skutecznego zarządzania deszczówką.

\section{Funkcje wody i znaczenie wód opadowych na terenach zurbanizowanych}

Woda jest elementem warunkującym życie. Proces osadniczy był niemal zawsze związany z lokalizacją w pobliżu wody ze względów bytowych i strategicznych (choć znane są miasta, które były lokowane z innych przyczyn i do dziś borykają się z problemami z wodą). Opady atmosferyczne są istotnym elementem obiegu wody w przyrodzie. Jednakże na skutek niezrównoważonego procesu rozwoju obszarów zurbanizowanych i wiejskich zaczęły być postrzegane jako źródło zagrożenia lub czynnik wzmagający je. Współcześnie zarządzanie wodą opadową staje się najistotniejszym zadaniem warunkującym skuteczne i efektywne gospodarowanie wodami w zlewni' ${ }^{1}$.

Zagadnienie wody deszczowej na terenach zurbanizowanych jest złożone i trzeba je rozpatrywać w szerszym kontekście. Powiązania miasta z wodą są bardzo szerokie i mogą być badane na wielu płaszczyznach: gospodarczej, kulturowej, społecznej, estetycznej, technologicznej, administracyjno-legislacyjnej². Nie wchodząc dogłębnie w poszczególne kategorie, należy jednak zdefiniować funkcje, jakie woda pełni w mieści, i można to uczynić z kilku perspektyw. Można rozpatrywać je z punktu widzenia koncepcji usługi ekosystemów, konkurencyjnych potrzeb różnych użytkowników czy przez pryzmat korzyści i zagrożeń.

Przez usługi ekosystemów (ecosystem services ${ }^{3}$ ) można najogólniej rozumieć całość korzyści, które człowiek (społeczeństwo) czerpie - świadomie lub nieświa-

${ }^{1}$ J. Królikowska, A. Królikowski, Wody opadowe: odprowadzanie, zagospodarowanie podczyszczanie $i$ wykorzystywanie, Seidel-Przywecki, Józefosław 2012, s. 9.

${ }^{2}$ Poradnik TEEB dla miast: ustugi ekosystemów w gospodarce miejskiej, thum., i red. wyd. pol. Fundacja Sendzimira, Kraków 2011, s. 1.

3 Jak w przypadku większości terminów tłumaczonych z języka angielskiego, przyjęte dosłowne tłumaczenie budzi wiele dyskusji, gdyż zgodnie z definicją SJP usługa to wykonywanie 
domie - z przyrody. Są to zarówno wytwory, jak i funkcje (ekonomista powiedziałby produkty i usługi).

Przyjmując podstawowy podział usług ekosystemów na zaopatrujące, regulacyjne, siedliskowe i kulturowe, w przypadku ekosystemów wodnych możemy wyróżnić wiele funkcji, z których najważniejsze są wskazane w tabeli 1. Jednak z punktu widzenia wody deszczowej należy zwrócić szczególną uwagę na funkcje regulacyjne. Jeżeli woda opadowa może swobodnie wsiąkać w ziemię, stanowi ważny element ochrony przeciwpowodziowej i jest istotna w zapobieganiu suszy. W przeciwnym wypadku może wpływać na nasilanie się tych procesów (szybki spływ powierzchniowy). Woda deszczowa stanowi istotny element w procesie regulacji mikroklimatu miasta, oczyszcza powietrze i powierzchnię miasta z zanieczyszczeń, wpływa na obniżenie temperatury.

Tabela 1. Wybrane funkcje wody w oparciu o koncepcję usługi ekosystemów

\begin{tabular}{|c|l|l|}
\hline Lp. & $\begin{array}{c}\text { Usługi } \\
\text { ekosystemów }\end{array}$ & \multicolumn{1}{c|}{ Funkcja } \\
\hline 1 & 2 & \multicolumn{1}{c|}{3} \\
\hline 11 & zaopatrujące & $\begin{array}{l}- \text { utrzymanie życia } \\
- \text { dostarczanie wody pitnej } \\
- \text { dostarczanie wody do celów produkcyjnych } \\
- \text { woda dla ekosystemów } \\
- \text { baza żywieniowa }\end{array}$ \\
\hline 22 & regulacyjne & $\begin{array}{l}\text { - retencja, regulacja przepływów hydrologicznych, zatrzymywanie } \\
\text { wody opadowej } \\
- \text { odbiór i neutralizacja ścieków (w granicach możliwości ekosyste- } \\
\text { mów), kontrola biologiczna } \\
- \text { oczyszczanie powierzchni miasta } \\
- \text { oczyszczanie wód (przesiąkanie) } \\
- \text { jakość powietrza (oczyszczanie z pyłów, obniżanie temperatury) } \\
- \text { wzbogacanie powietrza i gleby w wilgoć }\end{array}$ \\
\hline 33 & stymulowanie ruchów konwekcyjnych powietrza \\
\hline
\end{tabular}

pracy służącej bezpośrednio zaspokajaniu potrzeb. Zatem polskie tłumaczenie terminu ecosystem services nie jest ani zgodne z zakresem merytorycznym terminu angielskiego (bo obejmuje również produkty i zaspokaja potrzeby nie tylko bezpośrednio, ale i pośrednio), ani z polskim znaczeniem użytych słów. Niektórzy autorzy proponują zastąpienie słowa „usługi” terminem „,́́wiadczenie”, ale ten termin jest z kolei powiązany merytorycznie ze zobowiązaniem, a tu takie nie występuje. Według autorki najlepszym polskim odpowiednikiem byłoby określenie „przysługi środowiskowe”, które mimo iż poprawne merytorycznie zapewne się nie przyjmie. Mając jednak pełną świadomość wszystkich kontrowersji wokół tego terminu, używany będzie najbardziej popularny w polskiej literaturze naukowej termin: „usługi ekosystemów”. 
Tab. 1 (cd.)

\begin{tabular}{|c|l|l|}
\hline 1 & \multicolumn{1}{|c|}{2} & \multicolumn{1}{|c|}{3} \\
\hline 44 & kulturowe & - estetyka przestrzeni \\
& & $\begin{array}{l}\text { - pozytywny wpływ na zdrowie } \\
\text { - rekreacja } \\
\end{array}$ \\
& & - edukacja \\
& & podnoszenie wartości nieruchomości \\
\hline
\end{tabular}

Źródło: opracowanie własne na podstawie klasyfikacji z: Ekonomia ekosystemów i bioróżnorodności w polityce lokalnej i regionalnej. Poradnik TEEB dla miast: ustugi ekosystemów w gospodarce miejskiej, tlum. i red. wyd. pol. Fundacja Sendzimira, Kraków 2011, s. 3-4.

Wspomniane podejście konkurujących użytkowników ma większe znaczenie w przypadku samych zasobów wodnych i presji na nie, mniejsze zaś w odniesieniu do deszczówki, choć są to oczywiście elementy powiązane, gdyż brak opadów wpływa na dostępność wody. W tym kontekście istotne jest zapewnienie optymalnej ilości wody o określonej jakości dla rolnictwa, energetyki, przemysłu, ludności - bez zwiększania presji na ekosystemy. To podejście prowadzi jednak do bardzo trafnego - choć oczywistego - spostrzeżenia, że wymagana jest współpraca pomiędzy różnymi interesariuszami korzystającymi z zasobów wodnych. Liczne konflikty, jakie powstają w związku z gospodarowaniem wodą, wskazują jednak, że ta oczywista konstatacja nie przekłada się wystarczająco na praktykę. Dobrym przykładem konfliktów wokół wody deszczowej jest odwadnianie dróg, w tym nowo budowanych dróg ekspresowych. Znane są przypadki, gdy po powstaniu drogi okoliczne miejscowości, które nigdy wcześniej nie cierpiały z powodu zalań, są podtapiane wodami deszczowymi, mimo wykonania wszystkich odwodnień zgodnie z normami.

Można też spojrzeć na funkcje wody na terenach zurbanizowanych przez pryzmat korzyści i zagrożeń. Do pierwszej kategorii należy zaliczyć wszystkie funkcje związane z zaopatrzeniem w wodę, poprawą jakości życia, mikroklimatu, estetyki. Z drugiej strony jawi się zagrożenie powodzią i zagrożenie związane z zanieczyszczeniami odprowadzanymi do wód i gruntu oraz wszystkimi tego skutkami. W radzeniu sobie z zagrożeniem powodzią i suszą można wyróżnić trzy trendy:

- odsuwanie wody od ludzi,

- odsuwanie ludzi od wody,

- zrównoważone i zintegrowane zarządzanie wodą.

Pierwsze podejście związane jest z kosztowną infrastrukturą przeciwpowodziową, która w praktyce okazuje się często nie tyle nieskuteczna, ile przeciwskuteczna. Obwałowania rzek i ich regulacja powodują zmniejszenie możliwości rozlewania się rzek, zmniejszenie pojemności koryta i przyspieszenie spływu fali powodziowej. Jednocześnie tworzą złudne poczucie bezpieczeństwa 
i zagospodarowywanie terenów zagrożonych zalaniem. Tym samym w razie powodzi szkody i straty są wielokrotnie wyższe. Należy rozumieć potrzebę ich wykorzystania w określonych miejscach (np. centrach miast), ale odchodzić od ich nadużywania na terenach niezurbanizowanych lub tworzyć specjalne tereny zalewowe. W podejściu drugim - a więc „odsuwaniu ludzi od wody” - dominuje pogląd o konieczności ograniczania zabudowy na terenach zalewowych, a nawet wykupywania terenów zagrożonych zalaniem i przenoszenia stamtąd domostw i zaplecza gospodarczego, a przede wszystkim infrastruktury krytycznej. Wydaje się, że niezbędnym elementem takiego działania jest właśnie niedopuszczanie do osiedlania się na takich obszarach ${ }^{4}$, a niezbędnym minimum - przenoszenie z tych obszarów infrastruktury wrażliwej oraz specjalne wytyczne dla budowanych tam obiektów (zakaz budowania piwnic, obowiązek budynków dwukondygnacyjnych, na podwyższeniu, obowiązek lokalizowania drogiej infrastruktury na piętrze).

Natomiast w ostatnim podejściu kładzie się nacisk na szersze spojrzenie na kwestie wody w kontekście całej zlewni i procesów zarówno antropogenicznych, jak i naturalnych (w tym klimatycznych). Należy zatem uwzględniać system cieków i zbiorników wodnych, budowę geologiczną, opady i ich intensywność oraz sposób gospodarowania w zlewni, a więc i procesy urbanizacyjne. W tym podejściu kwestie wody opadowej i jej spływu są niezwykle istotne. Kładzie się nacisk na wykorzystanie naturalnych procesów: infiltracji, retencji, ewaporacji, czyli zielonej i niebieskiej infrastruktury5.

\section{Podstawowe przyczyny eskalacji problemów z deszczówką}

Można wskazać dwie główne grupy problemów, które przyczyniają się do wzmagania kłopotów z wodami deszczowymi: naturalne i antropogeniczne. Dane dotyczące opadów, w Polsce w tym opadów nawalnych, zostaną przybliżone w następnej części artykułu.

${ }^{4}$ Nowelizacja ustawy Prawo wodne z dn. 16 grudnia 2015 r. znosi obowiązek uwzględniania w planach zagospodarowania przestrzennego, decyzjach o lokalizacji inwestycji celu publicznego i warunkach zabudowy uwzględnianie zapisów map zagrożenia i ryzyka powodziowego, jest ono jedynie fakultatywne - a więc jest to krok w tył, http://urbnews.pl/zagrozenie-powodziowe-nie-bedzie-odwzorowane-w-planach-miejscowych/ (dostęp: 27.12.2015).

5 Zielona i niebieska infrastruktura to ,strategicznie zaplanowana sieć obszarów naturalnych i półnaturalnych z innymi cechami środowiskowymi, zaprojektowana i zarządzana w sposób mający zapewnić szeroką gamę usług ekosystemowych. Obejmuje ona obszary zielone (lub niebieskie w przypadku ekosystemów wodnych) oraz inne cechy fizyczne obszarów lądowych (w tym przybrzeżnych) oraz morskich. Na lądzie zielona infrastruktura jest obecna na obszarach wiejskich i w środowisku miejskim", Komunikat Komisji do Parlamentu Europejskiego, Rady, Europejskiego Komitetu Ekonomiczno-Społecznego i Komitetu Regionów: „Zielona infrastruktura - zwiększanie kapitału naturalnego Europy", COM(2013) 249 final. 
Głównym problemem antropogenicznym jest wzmożony spływ powierzchniowy do zbiorników o ograniczonej pojemności (często na skutek działalności gospodarczej). Wzmożony spływ powierzchniowy występuje zarówno na powierzchni utwardzonej, jak i na ziemi pozbawionej naturalnej różnorodnej roślinności, a więc polach uprawnych czy też trawnikach (choć mniejszy niż z powierzchni utwardzonych). Powoduje to, z jednej strony, zmniejszone przesiąkanie deszczu, a więc przesuszanie ziemi, zanikanie różnorodności roślin, pustynnienie, a w konsekwencji degradację struktur gleby. Z drugiej strony, zwiększa się ryzyko powodzi (i kumulacji fali powodziowej - rysunek 1) i lokalnych podtopień oraz niekontrolowanego okresowego doprowadzania zanieczyszczań do odbiorników. Przykładowe hydrogramy zlewni zurbanizowanej i niezurbanizowanej przedstawia rysunek 1 .

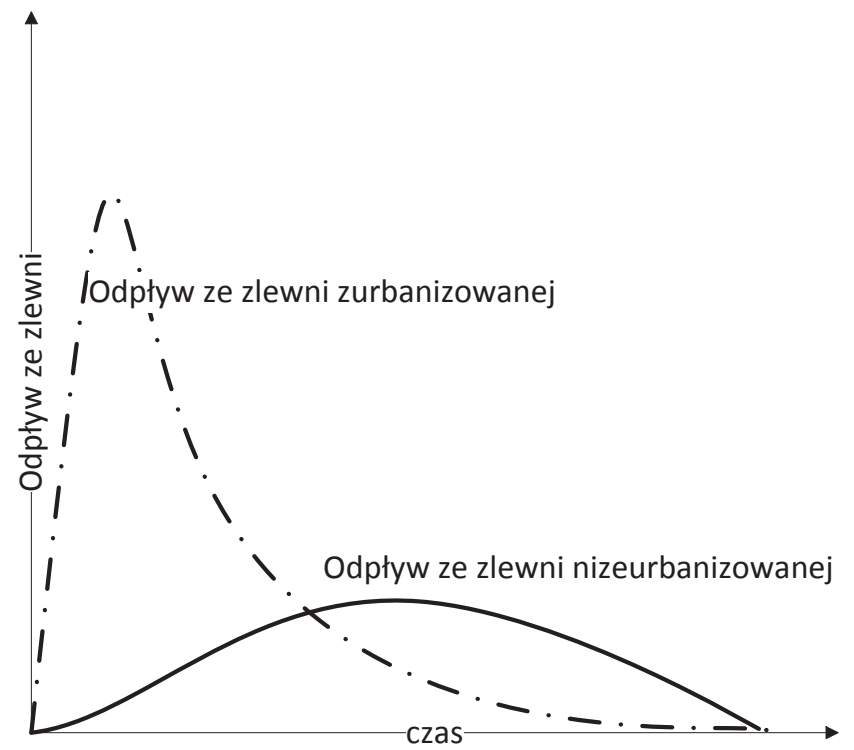

Rysunek 1. Hydrogramy odplywu wód w zlewniach zurbanizowanych i niezurbanizowanych

Źródto: E. Wojciechowska i in., Zrównoważone systemy gospodarowania woda deszczowa..., s. 19.

Pokazane w tabeli 2 szacunki udziału ewapotranspiracji (parowanie $\mathrm{z}$ gruntu i z roślin), spływu powierzchniowego, odpływu podziemnego i inflitracji pokazują, jak wielki wpływ na odpływ opadów ma kwestia uszczelnienia terenu. Prowadzone szczegółowe badania dowodzą, że ma to większe znaczenie niż spadek powierzchni ${ }^{6}$.

${ }^{6}$ B. Brzymek, E. Jarosińska, Wpływ uszczelnienia powierzchni zlewni na odplyw wód deszczowych, „Czasopismo Techniczne” 2012, z. 4: „Środowisko”, z. 1-Ś, s. 50. 
Tabela 2. Odpływ opadu w zależności od stopnia uszczelnienia

\begin{tabular}{|l|c|c|c|c|c|}
\hline Wyszczególnienie & $\begin{array}{c}\text { Udział } \\
\text { powierzchni } \\
\text { szczelnej (w \%) }\end{array}$ & $\begin{array}{c}\text { Ewapotran- } \\
\text { spiracja } \\
\text { (w \%) }\end{array}$ & $\begin{array}{c}\text { Splyw po- } \\
\text { wierzchniowy } \\
\text { (w \%) }\end{array}$ & $\begin{array}{c}\text { Odpływ } \\
\text { podziemny } \\
\text { (w \%) }\end{array}$ & $\begin{array}{c}\text { Infiltracja } \\
\text { (w \%) }\end{array}$ \\
\hline tereny naturalne & $\begin{array}{c}\text { powierzchnia } \\
\text { nieuszczelniona }\end{array}$ & 40 & 10 & 25 & 25 \\
\hline $\begin{array}{l}\text { zabudowa } \\
\text {,zagrodowa” }\end{array}$ & $10-20$ & 38 & 20 & 21 & 21 \\
\hline $\begin{array}{l}\text { zabudowa } \\
\text { „podmiejska” }\end{array}$ & $35-50$ & 35 & 30 & 20 & 15 \\
\hline $\begin{array}{l}\text { zabudowa } \\
\text { miejska }\end{array}$ & $75-100$ & 30 & 55 & 10 & 5 \\
\hline
\end{tabular}

Źródło: E. Wojciechowska i in., Zrównoważone systemy gospodarowania woda deszczową, Wydawnictwo Politechniki Gdańskiej, Gdańsk 2015, s. 27-28.

Należałoby też zadać pytanie, jak bardzo wzrasta udział powierzchni uszczelnionej w Polsce. Główny Urząd Statystyczny publikuje takie dane od 2004 r. (tabela 3). Wskaźnik ten jest wyznaczany jako udział powierzchni zabudowanej oraz zurbanizowanej i obejmuje:

- tereny mieszkaniowe, przemysłowe, inne tereny zabudowane,

- zurbanizowane tereny niezabudowane,

- tereny rekreacyjno-wypoczynkowe,

- tereny komunikacyjne,

- użytki kopalne.

Tabela 3. Udział powierzchni zabudowanej i zurbanizowanej w powierzchni ogółem

\begin{tabular}{|c|c|c|c|c|c|}
\hline Wyszczególnienie (w \%) & $\mathbf{2 0 0 4}$ & $\mathbf{2 0 0 5}$ & $\mathbf{2 0 1 0}$ & $\mathbf{2 0 1 4}$ & $\mathbf{2 0 1 5 *}$ \\
\hline $\begin{array}{l}\text { udział powierzchni zabudowanej } \\
\text { i zurbanizowanej w powierzchni } \\
\text { ogółem }\end{array}$ & 4,66 & 4,72 & 4,96 & 5,23 & 5,28 \\
\hline
\end{tabular}

Źródlo: dla lat 2004-2014: Wskaźniki zrównoważonego rozwoju Polski, GUS 2015, http://wskaznikizrp.stat.gov.pl/prezentacja.jsf?q=005003006001\&p=kraj, dla 2015 r.: obliczenia wtasne na podstawie: Rocznik statystyczny Rzeczypospolitej Polskiej 2015, GUS Warszawa, 2015, s. 100 tab. 1(12).

Przyrost w badanym okresie nie przekracza jednego punktu procentowego, więc wydaje się niewielki, ale jeżeli przeliczymy to na wartości naturalne (przyjmując powierzchnię lądową Polski $311888 \mathrm{~km}^{2}$ ), to otrzymujemy przyrost na poziomie blisko $2000 \mathrm{~km}^{2}$, czyli tak, jakby w okresie dziesięciu lat w Polsce przybyło sześć miast wielkości Krakowa (przyjęto powierzchnię 327 km²). Oczywiście tereny zaliczane do powierzchni zabudowanej i zurbanizowanej są uszczelnione 
w różnym stopniu, ale lepiej obrazuje to skalę procesu i wskazuje na fakt, iż procesy urbanizacyjne nie mogą być pomijane.

Uszczelnienie powierzchni powoduje szereg skutków wykraczających daleko poza skutki dla ekosystemów - skutków bezpośrednich i pośrednich. Autorka pozwoliła sobie rozszerzyć rozważania i wydzielić skutki pośrednie ekonomiczne związane ze wzrostem zużycia energii i wody do chłodzenia przegrzanych budynków, placów i ulic oraz podlewania roślin, które nie są w stanie skorzystać nawet z obfitych opadów, gdyż większość wody jest odprowadzana, a nie retencjonowana. $Z$ tego powodu rosną koszty utrzymania miasta, a jednoczesnie pojawiają się koszty podtopień (na skutek tzw. szybkich powodzi miejskiech). Należy zwrócić uwagę, że koszty te ponoszone są zarówno przez sektor prywatny, jak i publiczny.
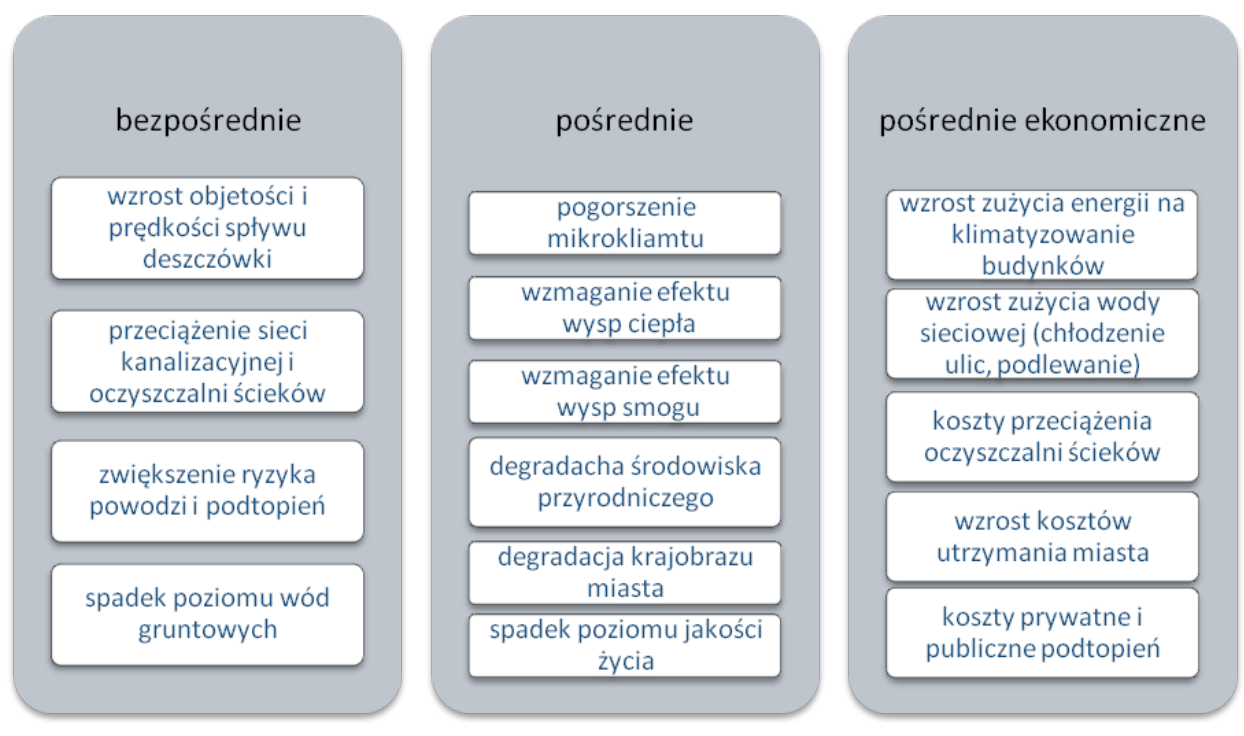

Rysunek 2. Skutki uszczelniania powierzchni na terenach zurbanizowanych

Źródto: opracowanie własne na podstawie: A. Janucha-Szostak, Miasto w symbiozie z woda, „Czasopismo Techniczne” 2010, z. 14: „,Architektura”, z. 6-A, s. 95-103.

\section{Opady atmosferyczne i ich intensywność}

Czynniki klimatyczne i geologiczne są jednymi z najistotniejszych w przypadku zarządzania wodami opadowymi. Trzy zasadnicze czynniki mają wpływ na ilość wód deszczowych: czas trwania deszczu, jego częstość (prawdopodobieństwo 
wystąpienia) oraz zasięg terytorialny . Natomiast badając skutki opadów, trzeba uwzględnić ukształtowanie terenu oraz jego zagospodarowanie.

Analiza danych dotyczących ilości opadów nie nastraja optymistycznie (tabela 4). Średnio w skali Polski w miesiącach ciepłych występuje 70 dni z opadami ponad $30 \mathrm{~mm}$, co może stanowić zagrożenie lokalnymi podtopieniami (liczone dni, gdy opad wystąpił chociaż na jednej stacji pomiarowej). Średnio mamy $58 \mathrm{dni}$ z opadami powyżej $50 \mathrm{~mm}$ na dobę, a jest to opad określony jako groźny powodziowo, w tym średnio 16 dni z opadami zaliczanymi do poziomu powodziowego i 5 do poziomu katastrofalnego. Oznacza to, że średnio 24\% dni w okresie 6 miesięcy letnich ma opady deszczu grożące powodziami (powyżej $50 \mathrm{~mm} /$ dobę), a w najgorszym 2010 roku było to ponad 32\% dni. Jednak licząc liczbę dni z opadami powyżej $30 \mathrm{~mm} /$ dobę, to prawie $40 \%$ dni w półroczu ciepłym jest potencjalnie zagrożonych ich wystąpieniem.

Tabela 4. Liczba dni z wysokim opadem dobowym na obszarze Polski w półroczu ciepłym (od maja do października) za okres 2001-2010

\begin{tabular}{|c|c|c|c|c|}
\hline $\begin{array}{r}\text { Powiom zagrożenia } \\
\text { powodzio- } \\
\text { wego }\end{array}$ & $\begin{array}{l}\text { Zagrażający } \\
\geq 30 \mathrm{~mm} / \text { dobę }\end{array}$ & $\begin{array}{c}\text { Groźny } \\
\text { powodziowo } \\
\geq 50 \mathrm{~mm} / \text { dobę }\end{array}$ & $\begin{array}{l}\text { Powodziowy } \\
\geq 70 \mathrm{~mm} / \text { dobę }\end{array}$ & $\begin{array}{l}\text { Katastrofalny } \\
\geq 100 \mathrm{~mm} / \text { dobę }\end{array}$ \\
\hline 2001 & 79 & 50 & 23 & 7 \\
\hline 2002 & 76 & 43 & 18 & 12 \\
\hline 2003 & 52 & 23 & 6 & 0 \\
\hline 2004 & 58 & 28 & 13 & 1 \\
\hline 2005 & 54 & 32 & 15 & 3 \\
\hline 2006 & 66 & 41 & 14 & 2 \\
\hline 2007 & 77 & 44 & 19 & 4 \\
\hline 2008 & 76 & 28 & 7 & 2 \\
\hline 2009 & 80 & 38 & 20 & 5 \\
\hline 2010 & 96 & 47 & 22 & 10 \\
\hline suma 2001-2010 & 711 & 374 & 157 & 46 \\
\hline średnia & 71 & 37 & 16 & 5 \\
\hline
\end{tabular}

Źródto: Klęski żywiołowe a bezpieczeństwo wewnętrzne kraju, red. H. Lorenc, IMGW Państwowy Instytut Badawczy, Warszawa 2012, s. 39.

${ }^{7}$ J. Królikowska, A. Królikowski, Wody opadowe..., s. 14. 
Jednakże opady i ich brak (susze) charakteryzuje duża nieregularność. W latach 2002 i 2010 było ponad 10 dni z opadami o skali katastrofalnej (powyżej $100 \mathrm{~mm}$ na dobę), a w roku 2001, 2009 i 2010 w półroczu ciepłym było ponad 20 dni z opadami powodziowymi (ponad $70 \mathrm{~mm}$ na dobę). Rok 2003 był natomiast jednym z najsuchszych lat w powojennej historii Polski i Europy ${ }^{8}$.

Zaznaczyć należy, że dane te pochodzą ze stacji pomiarowych IMGW, i dodać, że jedna z największych suszy miała miejsce w 2015 roku. Dane te nie zostały jednak uwzględnione w wykorzystywanym raporcie, ze względu na datę jego publikacji.

$\mathrm{W}$ tabeli 4 pokazano dane dotyczące dni deszczowych. Tabela 5 zawiera dane dotyczące obszarowego występowania opadów. Przez ,zdarzenie z wysokim opadem" rozumie się zanotowanie na danej stacji pomiaru opadu powyżej $30 \mathrm{~mm}$ /dobę (ponad 900 punktów pomiaru). Jeżeli w danym dniu taki opad zanotowano na 100 stacjach pomiarowych, występowało 100 ,zdarzeń”. Dane te wyjaśniają, dlaczego mimo że w latach 2002 i 2010 była podobna liczba dni z opadami $(\geq 50 \mathrm{~mm} /$ dobę w 2002 - 43 dni i w 2010 - $47 \mathrm{dni}, \geq 70 \mathrm{~mm} /$ dobę odpowiednio 18 i $22, \geq 100 \mathrm{~mm} /$ dobę odpowiednio 12 i 10), to występowało znacznie więcej zdarzeń, czyli opady występowały na większych obszarach dorzeczy ( $\geq 50 \mathrm{~mm} /$ dobę w 2002 - 452 zdarzenia i w 2010 - 1066 zdarzeń, $\geq 70 \mathrm{~mm} /$ dobę odpowiednio 160 i 342, $\geq 100 \mathrm{~mm} /$ dobę odpowiednio 37 i 75). Przestrzenne rozmieszczenie odpadów jest drugim ważnym czynnikiem obok ich intensywności. Na podstawie tych danych zostały stworzone mapy intensywności opadów. Z map tych wynika, że najczęstsze intensywne opady występują na południu Polski oraz w obszarach pojezierza pomorskiego?

Tabela 5. Liczba „,zdarzeń” z wysokim opadem dobowym na obszarze Polski w półroczu ciepłym (od maja do października) za okres 2001-2010

\begin{tabular}{|c|c|c|c|c|}
\hline $\begin{array}{r}\text { Powiom zagrożenia } \\
\text { powodzio- } \\
\text { wego }\end{array}$ & $\begin{array}{c}\text { Zagrażający } \\
\geq 30 \mathrm{~mm} / \text { dobę }\end{array}$ & $\begin{array}{c}\text { Groźny } \\
\text { powodziowo } \\
\geq 50 \mathrm{~mm} / \text { dobę }\end{array}$ & $\begin{array}{l}\text { Powodziowy } \\
\geq 70 \mathrm{~mm} / \text { dobę }\end{array}$ & $\begin{array}{l}\text { Katastrofalny } \\
\geq 100 \mathrm{~mm} / \text { dobę }\end{array}$ \\
\hline 1 & 2 & 3 & 4 & 5 \\
\hline 2001 & 1966 & 540 & 161 & 38 \\
\hline 2002 & 1720 & 452 & 160 & 37 \\
\hline 2003 & 816 & 108 & 13 & 0 \\
\hline 2004 & 815 & 182 & 35 & 1 \\
\hline
\end{tabular}

${ }^{8}$ H. Lorenc (red.), Klęski żywiołowe a bezpieczeństwo wewnętrzne Kraju, IMGW Państwowy Instytut Badawczy, Warszawa 2012, s. 38-40.

9 Tamże, s. 41. 


\begin{tabular}{|l|c|c|c|c|}
\hline \multicolumn{1}{|c|}{1} & 2 & 3 & 4 & 5 \\
\hline 2005 & 1316 & 284 & 61 & 5 \\
\hline 2006 & 1172 & 316 & 96 & 15 \\
\hline 2007 & 1914 & 445 & 99 & 9 \\
\hline 2008 & 1360 & 225 & 31 & 8 \\
\hline 2009 & 1422 & 240 & 57 & 75 \\
\hline 2010 & 3951 & 1066 & 342 & 202 \\
\hline suma 2001-2010 & 16462 & 3838 & 1055 & 20 \\
\hline średnia & 1646 & 383 & 105 & \\
\hline
\end{tabular}

Źródto: Klęski żywiołowe..., s. 39.

Kolejnym istotnym zagrożeniem jest tzw. powódź miejska. Nie jest ona związana zazwyczaj z wystąpieniem cieku wodnego z brzegów, ale z gromadzeniem się wody na terenach nieprzepuszczalnych w mieście w związku z niewydolnością systemów kanalizacyjnych i zbyt małą ilością obszarów umożliwiających przesiąkanie i retencję. Często wystarczy kilkunastominutowy lokalny gwałtowny opad, by doszło do znacznych podtopień. Jednocześnie przy dużej gęstości zabudowy i zgromadzonego majątku nawet relatywnie niewielkie podtopienia powodują duże straty. Niepokojący jest fakt, że liczba lokalnych nagłych powodzi (flash flood) gwałtownie wzrasta (tabela 6). Należy podkreślić, że również z terenów uprawnych spływ powierzchniowy jest kilkukrotnie wyższy niż z terenów z naturalną roślinnością, np. leśnych. Jednak takie zjawiska, choć mniej spektakularne, zachodzą również na terenach zaliczanych do wiejskich lub podmiejskich. Winą za wzmożony spływ z terenów niezurbanizowanych obarcza się zaniechania w melioracjach i małej retencji oraz zanikanie lokalnych małych terenów zalesionych i zagajników. Tu należy podkreślić, że taki spływ powierzchniowy zarówno na terenach zurbanizowanych, jak i nie niesie ze sobą wiele zanieczyszczeń, a w przypadków terenów uprawnych mogą to być nawozy lub środki ochrony roślin. Na podstawie analizy szczegółowej danych dotyczących nagłych powodzi lokalnych wyznaczono 32 obszary szczególnie narażone na ich występowanie. Większość z nich znajduje się na południu Polski, są to też niektóre obszary aglomeracyjne ${ }^{10}$. 
Tabela 6. Liczba nagłych powodzi i miejsc ich wystąpień* w Polsce w latach 1970-2010

\begin{tabular}{|c|c|c|}
\hline Lata & Liczba nagłych powodzi & $\begin{array}{c}\text { Liczba miejsc wystapień } \\
\text { naglych powodzi }\end{array}$ \\
\hline $1971-1980$ & 121 & 216 \\
\hline $1981-1990$ & 249 & 400 \\
\hline $1991-2000$ & 397 & 504 \\
\hline $2001-2010$ & 554 & 984 \\
\hline $1971-2010$ & 1321 & 2104 \\
\hline
\end{tabular}

* Jedno zjawisko pogodowe może wywołać podtopienia w kilku miejscach.

Źródto: Klęski żywiołowe..., s. 157-158.

Z przedstawionych danych wynika, że zdarzenia spowodowane przez gromadzenie się i spływ powierzchniowy wód opadowych występują coraz częściej i w większej intensywności. W połączeniu z rosnącym uszczelnieniem gruntu i zaniechaniami w melioracjach oraz $\mathrm{w}$ gospodarowaniu wodą na terenach zurbanizowanych tworzy to realne zagrożenie i przyczynę rosnących strat.

\section{Cele zarządzania wodami opadowymi}

Najogólniej, cel zarządzania wodami deszczowymi i roztopowymi powinien zostać określony jako: takie gospodarowanie wodami opadowymi, aby zminimalizować ryzyko powodzi i suszy oraz ograniczać zanieczyszczenia wód powierzchniowych i gruntowych, przy jednoczesnym stworzeniu możliwości do gospodarczego i przyrodniczego wykorzystania tych wód bez szkód dla ekosystemów wodnych i od wody zależnych.

Jednakże ten główny cel można rozłożyć na szereg celów szczegółowych, które zostały podzielone na kilka istotnych kategorii: ekologiczne, funkcjonalne, ekonomiczne i krajobrazowe, kulturowo-społeczne i prawne. Należałoby jeszcze podkreślić, że nie jest to zamknięty katalog.

Wszystkie wymienione kategorie i cele szczegółowe są niezwykle istotne, ale warto podkreślić znaczenie tych zaliczonych do grupy funkcjonalnych oraz kulturowo-społecznych. Tych pierwszych, ponieważ dzięki wykorzystaniu właściwych, nowoczesnych elementów zielonej i niebieskiej infrastruktury można rozwiązać szereg współczesnych problemów terenów zurbanizowanych i rolniczych, ale nie można ze ślepą ufnością ,przenosić” rozwiązań stosowanych na innych obszarach. Każdorazowo są wymagane szczegółowe analizy lokalnych uwarunkowań geograficznych i innych krytycznych czynników. Dlatego tak niezwykle ważne jest edukowanie władz lokalnych i zaangażowanie lokalnej społeczności. 


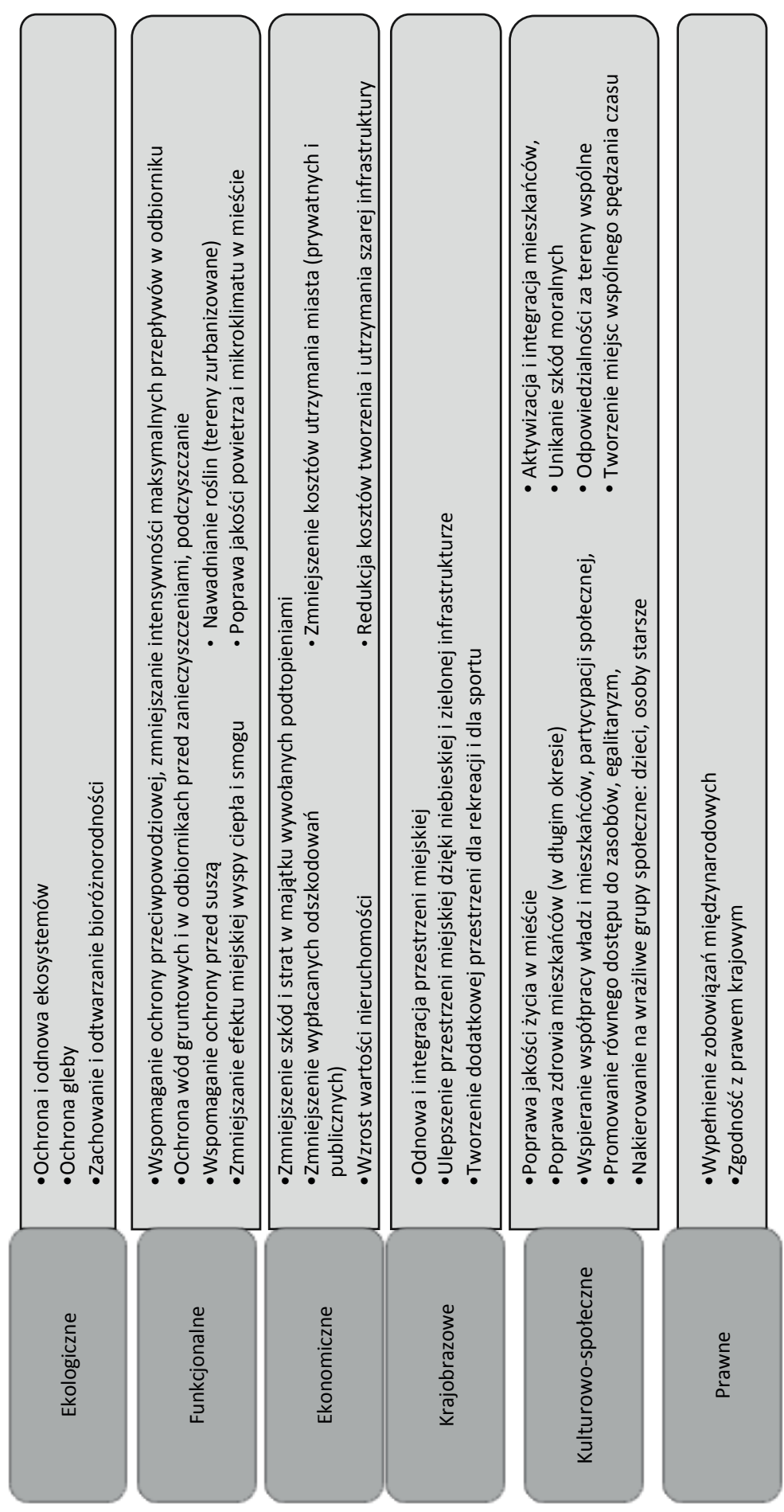

ญ.

हิ ป

要

ङ

กิ 8

$\therefore$

ฉ.

ริ

넌

$\therefore$

ปี

3

.$\sqrt[3]{2}$

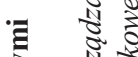

帘

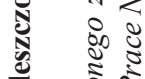

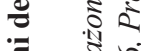

छ

है है

零

촌

ปั है ड़

क्ष

ए

ن :

ํำ

吾

咅

N

2.

ปี

की

ปै

से

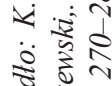

ㄴ.

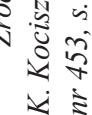


Z pewnością wymagana będzie szczególna ostrożność, gdy na terenach objętych projektem zmian znajdują się:

- osuwiska,

- kopalnie,

- wody uzdrowiskowe,

- wysoki poziom wód gruntowych,

- ujęcia wody pitnej.

\section{Podsumowanie}

Rosnące uszczelnienie powierzchni na skutek procesów urbanizacyjnych oraz przykładanie zbyt małej wagi do problemów zagospodarowania wody deszczowej stały się przyczyną dzisiejszych problemów. Dopiero potwierdzone obserwacje nasilających się gwałtownych zmian pogodowych, w tym opadów nawalnych, spowodowały większe zainteresowanie tym problemem w Polsce. Rozwiązanie tych problemównie jest proste, gdyż przyczyny leżą zarówno po stronie zmian klimatycznych, jak i działalności człowieka. Dane meteorologiczne potwierdzają spostrzeżenia, że zwiększa się gwałtowność zjawisk meteorologicznych, a to w połączeniu ze zmianami cywilizacyjnymi powoduje wzrost ryzyka wystąpienia podtopień, zwiększenie ryzyka powodziowego i nasilanie problemów z suszą. Konieczne jest zrozumienie, że problemy wynikające $\mathrm{z}$ traktowania deszczówki jako ścieku, który trzeba jak najszybciej odprowadzić, ma liczne konsekwencje zarówno na terenach zurbanizowanych, jak i rolniczych. To właśnie przyspieszony spływ zwiększa ryzyko powodzi i również suszy, gdyż woda nie jest zatrzymywana w ekosystemach.

Należy oczywiście pamiętać, że woda spływająca z powierzchni uszczelnionych może być zanieczyszczona i to substancjami niebezpiecznymi. Wypracowane współcześnie rozwiązania zielonej i niebieskiej infrastruktury zapewniają w dużej mierze podczyszczanie tych wód do takiego stopnia, że nie stanowią one zagrożenia dla ekosystemów.

Wodą deszczową należy gospodarować, gdyż jest ona cennym zasobem. Można i należy ją używać do celów gospodarczych (podlewanie, spłukiwanie toalet), jak również należy zwiększać naturalne retencjonowanie wody.

Efekty nieprawidłowego gospodarowania wodami deszczowymi wykraczają daleko poza bezpośrednie skutki. Powodują szereg oddalonych w czasie efektów pośrednich, takich jak degradacja środowiska oraz pogorszenie jakości życia i zdrowia ludności. Wskazać można również liczne pośrednie ekonomiczne negatywne skutki w postaci wzrostu kosztów utrzymania miasta (prywatnych i publicznych) oraz strat spowodowanych powodziami. Zdefiniowanie obszarów występowania niekorzyści wynikających z niewłaściwego gospodarowania wodami 
opadowymi daje szansę na wskazanie dziedzin, w których pozytywne zmiany wywołają najwięcej skutków pozytywnych. Niestety większość tych pozytywnych skutków jest również pośrednia, a część z nich trudnomierzalna. Ponieważ głównymi czerpiącymi korzyści ze zmiany podejścia będzie społeczeństwo i środowisko, wydaje się, że zadania te powinny być podejmowane. Dlatego niezbędne jest szerokie zdefiniowanie celów gospodarowania wodami opadowymi, choć głównym celem powinna być ochrona ekosystemów przed degradacją oraz zmniejszenie ryzyka wystąpienia powodzi i suszy.

\section{Bibliografia}

Brzymek B., Jarosińska E., Wpływ uszczelnienia powierzchni zlewni na odpływ wód deszczowych, „Czasopismo Techniczne” 2012, z. 4: „Środowisko”, z. 1-Ś, s. 50.

Ekonomia ekosystemów i bioróżnorodności w polityce lokalnej i regionalnej. Poradnik TEEB dla miast: ustugi ekosystemów w gospodarce miejskiej, tłum. i red. wyd. pol. Fundacja Sendzimira, Kraków 2011.

Januchta-Szostak A., Miasto w symbiozie z woda, „Czasopismo Techniczne” 2010, z. 14: „Architektura", z. 6-A, s. 95-103.

Komunikat Komisji do Parlamentu Europejskiego, Rady, Europejskiego Komitetu Ekonomiczno-Społecznego i Komitetu Regionów: ,Zielona infrastruktura - zwiększanie kapitału naturalnego Europy", $\operatorname{COM(2013)} 249$ final

Królikowska J., Królikowski A., Wody opadowe: odprowadzanie, zagospodarowanie podczyszczanie $i$ wykorzystywanie, Seidel-Przywecki, Józefosław 2012.

Lorenc H. (red.), Klęski żywiołowe a bezpieczeństwo wewnętrzne kraju, IMGW Państwowy Instytut Badawczy, Warszawa 2012.

Rocznik statystyczny Rzeczypospolitej Polskiej 2015, GUS, Warszawa 2015.

Opłaty od powierzchni uszczelnionej jako instrument zrównoważonego zarzadzania wodami opadowymi i roztopowymi, red. K Kociszewski,. Wydawnictwo Uniwersytetu Ekonomicznego we Wrocławiu Wrocław 2016, Prace Naukowe Uniwersytetu Ekonomicznego we Wrocławiu, nr 453, s. 270-0 281.

Wojciechowska E. i in., Zrównoważone systemy gospodarowania wodą deszczowa, Wydawnictwo Politechniki Gdańskiej, Gdańsk 2015.

Wskaźniki zrównoważonego rozwoju Polski, GUS 2015, http://wskaznikizrp.stat.gov.pl/prezentacja.jsf?q=005003006001\&p=kraj (dostęp: 27.12.2015).

http://urbnews.pl/zagrozenie-powodziowe-nie-bedzie-odwzorowane-w-planach-miejscowych/ (dostęp: 27.12.2015).

\section{Streszczenie}

Woda deszczowa powinna zacząć być traktowana nie jako odpad, a jako cenny zasób, którym należy mądrze gospodarować w celu zmniejszenia ryzyka podtopień i powodzi, przeciwdziałania suszy, poprawy jakości życia na terenach zurbanizowanych, zapewnienia nawodnień dla rolnictwa. Można i należy wykorzystywać naturalne procesy w celu oczyszczania tejże wody. 
Proponowane rozważania są pierwszym etapem szerszych badań związanych z gospodarowaniem wodami opadowymi. Celem artykułu jest rozpoznanie tematyki wody deszczowej w kontekście problemów z zarządzaniem nią, zdefiniowanie problemów i ich przyczyn oraz celów skutecznego zarządzania deszczówką.

Słowa kluczowe: wody opadowe, gospodarowanie deszczówką, cele gospodarowania wodami opadowymi, zarządzanie wodami opadowymi 